\title{
Understanding the Rudiments of Media Research Methodology: Content Analysis of Daily Trust, a Nigerian Daily Newspaper
}

\author{
Adamkolo Mohammed Ibrahim ${ }^{1,2}$, Balarabe Maikaba ${ }^{2}$, Suleiman Mainasara Yar'Adua ${ }^{2}$ \\ ${ }^{1}$ Department of Mass Communication, University of Maiduguri, Maiduguri, Nigeria \\ ${ }^{2}$ Department of Mass Communication, Bayero University, Kano, Kano, Nigeria \\ Correspondence: Adamkolo Mohammed Ibrahim, Department of Mass Communication, University of Maiduguri, PMB \\ 1069 Maiduguri, Borno State, Nigeria. E-mail: adamkolo@unimaid.edu.ng
}

Received: July 17, 2019

doi:10.11114/smc.v7i2.4385
Accepted: August 12, $2019 \quad$ Online Published: September 8, 2019

URL: https://doi.org/10.11114/smc.v7i2.4385

\begin{abstract}
Newspaper journalism is a vast area of research that has gained much attention from academics and media industry. Because of the immense contribution of media to social, economic, political and cultural development to societies, understanding the links and impacts of media and media content on audiences and the polity has been stressed. Democracy has been shown to be a means to an end, and public opinion and participation are invariably shown to affect and be affected by democracy and media content. By its unique characteristics (private ownership, less state influence, greater independence, ability to criticize the state, etc.) newspaper has been shown to influence government and public agenda and set agenda for broadcast and online media. One of the popular methodological approaches adopted in media agenda-setting research is content analysis. Based on the Agenda-Setting theory, this paper employed a quantitative content analysis approach to provide an understanding about the content of Daily Trust newspaper (a Nigerian national daily) in order to provide some guidance on the practical skills and theoretical knowledge about content analysis both as a methodology and theoretical framework for the benefits of postgraduate media content analysis students and researchers. The findings showed that pictures, headlines and news stories were the dominant units of analysis while politics (democracy, governance and party politics) religion and crisis (ethno-religious crises issues surrounding the herdsmen-farmers conflict) were the dominant content categories. Daily Trust newspaper should continue embracing development and peace journalism trend of journalism.
\end{abstract}

Keywords: agenda-setting theory, content categories, Daily Trust newspaper, editorial content, postgraduate students, quantitative content analysis, units of analysis

\section{Introduction}

Newspaper journalism and politics have a long history of juxtaposition in Nigeria, dating back to the first newspaper: Iwe Iroyin fun Awon Ara Egba ati Yoruba (Newspaper for the Egbas and Yoruba). The maiden issue of the newspaper Iwe Iroyin fun Awon Omo Egba Ati Yoruba was first seen on Abeokuta streets, churches, and schools on December 3rd, 1859 and had an existence of eight years (1859-1867) while the pioneer of the first African newspaper to publish in an African language, Reverend Henry Townsend stated his purpose as getting "the people to read and to beget the habit of seeking information by reading (Olomojobi, 2017; Oyesomi, Salawu \& Oyenankeya, 2019; Daramola, 2013). The newspaper which later became a weekly bilingual, had eight pages and published a wide range of news; birth, deaths, movement of religious ministries, parish news, baptismal and confirmation news, political news, especially those concerning Abeokuta and environ. Iwe Iroyin also carried commercial news about produce prices for palm oil, and included news about colonial administration, some foreign news, advertisements and public announcements in its editions" (Duyile, 1987, p. 17).

The paper began two separate editions in English and Yoruba in 1866 to confirm that the newspaper thrived well and was a force to be reckoned with during the time as it provided the early elites with literature, educated the growing public about history and politics of the time, and played advocacy role in fight against slave trade. It was the fore runner of the first Yoruba Bible in 1862, people came to employ the newspaper as the chief weapon by which they were to exercise their power of participation in the government of their land. (Daramola 2005, p. 13) 
This paper research paper was written with the aim of exhaustively identifying the content categories and units of analysis of a weekend edition of a national daily newspaper (Daily Trust) based on frequency and percentage quantitatively in order to serve as a practical training for postgraduate content analysis students in a partial fulfillment for the requirements of a one-semester course work in a three-year postgraduate, specifically Doctoral/PhD programme at the Department of Mass Communication in the Faculty of Communication, Bayero University, Kano (BUK), Nigeria.

Because of the immeasurable important role media of mass communication play in building society, scores of thousands of people enroll in colleges and institutions of higher learning to study courses related to communication media such as Mass Communication and Journalism and conduct research studies leading to the award of various academic degrees. Many Nigerian erudite scholars such as Professors Umaru Pate and Balarabe Maikaba as well as Drs. Mainasara Kurfi, $\mathrm{PhD}$, Suleiman M. Yar'Adua, $\mathrm{PhD}$, etc. teach and conduct research in Mass Communication and Journalism studies as a career. Since 1940s, Mass Communication has evolved not only as an area of study but also as a field of research. Often categorised under social science (Yusha'u, 2009), research in Mass Communication and Journalism employs an array of artistic/humanistic, scientific and experimental methodologies. Content analysis is one of such methods, which has gained a wider application especially in media content studies (Oyesomi et al., 2019).

With the advent and subsequent overwhelming developments in internet technology (Maikaba, 2017), especially Web 2.0 and social media three major categories of communication media (the print, broadcast and online, or internet-based media) are struggling for research attention from content analysis research students and scholars. Given that content analysis chiefly focuses on the content of a given medium under investigation and the content of each of those three forms of media can be suitable for content analysis. However, over the years, newspaper has been one of the most popular media used in content analysis (Krippendorff, 2004). In addition, content permanence, portability and easier access to the content add to the advantages of the medium over either of the remaining two media types (broadcast and online). For the purpose of the present study, the entire content of Daily Trust tabloid national daily newspaper Vol. 14, No. 16, published on Sunday 7th July 2019 was analysed. The Agenda Setting theory approaches was adopted in the data analysis.

The Daily Trust newspaper is published alongside Weekly Trust newspaper, as an innovative, versatile and market driven newspaper. Together, they constitute the largest circulating newspapers in northern Nigeria. Daily Trust was established in January 2001 and was the first daily newspaper from the Federal Capital Territory (Abuja). The Daily Trust newspaper is printed and published by Media Trust Limited Abuja. The online site is well organised, simple, content rich and easy to navigate. The company first came out with the Weekly Trust on March 21, 1998 and the publisher is Alhaji Kabiru Yusuf, a senior lecturer of the Department of Political Science, Usman Dan Fodio University, Sokoto. The newspaper, according to Daramola (2013, p. 146-7) "is more prominent in the Northern part of the country and pursues northern agenda". The Daily Trust and Weekly Trust became the largest circulating newspaper in northern Nigeria as from year 2000 and are distributed in all towns and cities in the North; Lagos, Abeokuta and Ibadan in the South-West; Yenogoa, Benin, Calabar in the South-South; Onitsha, Owerri and Enugu in the South-East; and in various outlets in London, England, etc. (Alawode \& Adesanya, 2016).

Furthermore, this study was hinged on the philosophy of 'learning through experiential practice', which coincides with the adage: 'practice makes perfect'. The term practice has Greek origin (praksis, prakseos) and it means "activity, action, deeds" (Bim-Bad \& Egorova, 2016, p. 3387). A retrospective analysis of scientific works suggests that fundamental explanation of the word "practice" was the concept of "strength" in the meaning of steadiness, decency, pride, moral deed, good, freedom and later in the meaning of condition, driving force, cause of a process. For instance, ancient Greeks, including Socrates and Plato, Aristotle, understood practice as human activity, actions, aimed at respective goals, at finding the truth for the sake of it. Aristotle thought that knowledge should be assimilated during practical work (Stepashko, 1999). Hence, the purpose of this study is to demonstrate the practical skills and knowledge of conducting a quantitative content analysis of a print medium. This is expected to provide novice communication research students with some basic knowledge about how to write content analysis essays or perform media studies using content analysis methods.

\subsection{Objectives of the Study}

This study focuses on providing an exhaustive content analysis on the entire content of Daily Trust newspaper Vol. 14, No. 16, published on Sunday 7th July 2019, which was equivalent to 4th Dhul-Qa'adah 1440 of Islamic calendar. The selected newspaper has a cover price of N250 and was printed in 48 pages. This study was performed to achieve four objectives namely to: (i) exhaustively identify mutually exclusive content categories and units of analysis in the selected edition of Daily Trust newspaper; (ii) analyse the entire editorial content of the newspaper quantitatively based on frequency and percentage; (iii) identify the dominant variable in the content of the newspaper; and (iv) discuss the likely reasons for the dominance of the variable in the content in relation to the agenda-setting role of the selected newspaper. 


\section{Literature Review}

\subsection{Concept of Content Analysis}

Content analysis as a research technique has been used by different scholars in different fields. It is a research process that involves a rigorous procedure of investigation in order to arrive at a conclusion that is systematic and empirical by using certain categories and coding procedures that are standard and informed by the understanding of the topic or concept under investigation. The researcher using content analysis observes, in a systematic way, what the manner of communication content symbolizes (Kolbe \& Burnett, 1991). As a research technique in the social sciences, content analysis became popular and its application increased in the early 1950s as a result of the work of Berelson who provided an insight into the analysis of communication research using content analysis (Mitchell, 1967; Yusha'u, 2009).

Other studies have shown that content analysis has been used since 1914, this was so because of its ability to use "on-quantified" "verbal material" into a "quantitative data" that can be "manipulated for purposes of description or hypothesis testing" (Winham, 1969, p. 192). In content analysis, there is broader understanding of communication content, which can involve both manifest (Kaplan, 1943), and latent meanings, and its application includes "the application of historical, cultural, psychological, and legal frames of reference with various levels of meaning, subtitles, and efforts at explication of ambiguities" (Janowitz, 1969, p. 648), and as discussed by Kassarjian (1977) the focus of content analysis is on the messages itself. According to Janowitz (1969) content analysis seeks to infer on the reasons behind communication messages, the methods employed by the originator of the message and the aims he or she wants to achieve (Yusha'u, 2009).

Kassarjian (1977) looked at various definitions of content analysis proffered by different scholars such as Berelson, Fearing, Barcus, Paisley, Budd et al, Kerlinger and Laswell et al. The definition of content analysis offered by these scholars in the 1950s and 1960s marked the understanding of content analysis today. Drawing from the works of these scholars, content analysis can summarily be defined as a study of communication content in a descriptive, systematic, objective and empirical way. It produces both manifest and latent meaning of communication, the emphasis is on the message rather than the disseminator of the message, though it seeks to uncover and observe the intention behind the message by using rigorous coding procedures and identifiable categories (McNamara, 2005). Carley (1993) states that "the basic idea" in content analysis "is to take a list of concepts and a set of texts and then simply count the number of times each concept occurs in each text. Differences in the distribution of counts across texts provide insight into the similarities and differences in the content of the text." Carley went further by defining a concept as simply an "ideational kernel" irrespective of whether it is a single word or phrase (p. 81). Content analysis has some distinguishing features namely, "objectivity, systematisation and quantification, though content analysis can also be qualitative in nature" (Yusha'u, 2009, p. 125).

Berelson (1952) suggested five main purposes of content analysis as follows:

1) To describe form characteristics of message content

2) To make inferences to producers of content

3) To make inferences to audiences of content

4) To predict the effects of content on audiences

Carney (as cited in McNamara, 2005) broadly agreed with this view summarising the three main uses of content analysis as (a) descriptive; (b) hypothesis testing and (c) facilitating inference (p. 52).

\subsubsection{Quantitative and Qualitative Content Analyses}

Quantitative content analysis collects data about media content such as topics or issues, volume of mentions, 'messages' determined by key words in context (KWIC), circulation of the media (audience reach) and frequency. Quantitative content analysis also should consider media form (e.g., visual media such as television use more sophisticated semiotic systems than printed text and, thus, are generally regarded as having greater impact). Neuendorf (2002) says: "What's important is that both content and form characteristics ought to be considered in every content analysis conducted. Form characteristics are often extremely important mediators of the content elements" (p. 24). While Neuendorf argues that media content analysis is quantitative only, Shoemaker and Reese's categorisation of content analysis into humanist and behaviourist traditions indicates that content analysis can be undertaken using both approaches (McNamara, 2005).

Cited in McNamara (2005) Neuman (1997), in a widely used text on social research methodology, comments on the quantitative-qualitative dichotomy in content analysis: "In content analysis, a researcher uses objective and systematic counting and recording procedures to produce a quantitative description of the symbolic content in a text" but he adds "there are qualitative or interpretative versions of content analysis". Neuman notes: "Qualitative content analysis is not highly respected by most positivist researchers. Nonetheless, feminist researchers and others adopting more critical and interpretative approaches favour it” (p. 273). 


\subsection{Theoretical Background}

\subsubsection{Agenda-Setting Theory}

The agenda-setting theory is one of the media effects theories in the field of mass communication. The major premise of the agenda-setting theory is that the media set the agenda for what the public would deem important. According to the theory, there is a correlation between the media's presentation of news and information and the level of significance the public accord to events and issues in the society. Public discourse, often than not, revolve around issues that are frequently and consistently focused on by the media. How the media selectively highlight issues also influences the formation of opinion on such issues among members of the public (Neuman, Jan \& Bae, 2014; Oyesomi et al., 2019).

The development of the agenda-setting theory is credited to Maxwell, McCombs and Donald Shaw based on their seminal study published in 1972. The two researchers had earlier studied the 1968 US presidential election in Chapel Hill, North Carolina comparing news coverage of public issues in the news media and public issues esteemed by electorates as most important. An early sketch of the theory is linked to Walter Lipmann, whose 1922 book, Public Opinion, and specifically the opening chapter titled "The World Outside and the Pictures in Our Heads", advanced the argument that the media are the primary source of the pictures in the heads of the public "about the larger world of public affairs" (Olomojobi, 2017; Salman, 2016). The agenda-setting theory also draws from the assertion of Cohen (1963) who observed that the press "may not be successful much of the time in telling people what to think, but it is stunningly successful in telling its readers what to think about" (p. 120).

The agenda-setting theory is basically about the causal relationship between media agenda and public agenda. Rather than directly tell the public to consider one issue as more important than another, the media set agenda by giving preferential treatment to issues in their coverage (Zhu \& Blood, 1997). In similar vein, Grossberg, Wantella, Whitney and Wise (2006) affirm that the media cue the public to see certain issues as important by the prominence such issues are given and "by both the extensiveness of stories in a given day and duration of coverage over time" (p. 367). The process by which media agenda starts and leads to public agenda is captured by DeFleur (2010) in the following propositions:

1) The press (news media, in general) selects several issues, topics, and events from its continuous surveillance of the environment to process and report daily as "the news".

2) Because of limited space and time, and because of journalists' convictions as to what is "newsworthy", many issues and topics are ignored and do not become part of the news.

3) The press gives each of the news stories selected greater or lesser prominence in its reports by assigning it a given position, or giving it more or less space or time, in its print or broadcast news presentations.

4) The selection of stories presented, with their different levels of prominence, space and time, forms the news agenda of the press.

5) Therefore, when the public attends to these news reports, they will perceive the order of prominence assigned by the press in its agenda of stories and will use it to decide on a parallel personal ranking of importance of the issues and topics that make up the news. (p. 171).

There are generally two levels of agenda-setting: salience of objects and the salience of attributes (Kiousis \& McCombs, 2004, p. 38). The first level- salience of objects - which was the dominant focus of early studies on agenda-setting theory, refers to how the media beam attention on certain public issues (objects). Salience of attributes, being the second level, is a further step to the first level; here, the media not only focus on 'objects' (issues, topics, events and people- of public concern) but also highlight traits, aspects or characteristics of the particular object in focus. Aspects of an issue are not usually accorded equal attention by the media; while an aspect may be more emphasised, some get irregular attention and some others are altogether neglected. It is this propensity of the media to emphasise certain attributes of an issue that shapes how the public perceive, understand and form their opinions concerning such issue (Olomojobi, 2017). The two levels of the agenda-setting theory come to the fore when the mass media are involved in "calling attention to the new and major issues of the day and influencing agreement about what are the priorities of these issues", thus intersecting the surveillance and the consensus functions of the media (McCombs, 2005, p. 556).

\section{Methods}

\subsection{The Philosophy Behind this Study}

The ontological philosophy behind this study is for the candidate (the student) to understand and analyse the interactions between the various elements of the content of the selected newspaper among themselves and their relationships with the outside world, or the society in both time and space systematically based on an objectivist approach, majorly by explicating the ontological (research framework), epistemological (research questions/objectives) 
and methodological (research methods) units of the research process. From ontological perspective this paper seeks to situate the question of the analysis of the content of the newspaper under investigation into a philosophical prism of subjective objectivism rather than purely objectivism. Though this approach contradicts Berelson's (1952) definition of content analysis, which emphasizes objectivity and 'manifestation', or reliability, concepts that exclude what Krippendorff (2004) describes as "reading between the lines" a practice that experts perform, most of the time with "remarkable intersubjective agreement" (p.20). Objectivism (also known as positivism) portrays the position that asserts that social phenomena and their meanings have an existence that is independent of social actors. On the contrary, subjectivism (also known as constructivism or interpretivism) perceives that social phenomena are created from the perceptions and consequent actions of those social actors concerned with their existence. Whereas, subjective objectivism refers to the degree to which content analysis has been used to analyse quantitative (objective) data qualitatively (subjectively); and this study adopted this approach (Blaikie, 2010; Bryman, 2012; Krippendorff, 2004).

Furthermore, cited in Al-Saadi (2014), Cohen, Manion and Morrison (2007) say,

epistemology is about the assumptions which one makes about "the very bases of knowledge - its nature and form, how it can be acquired and how communicated to other human beings" (P.7). Furthermore, the authors stress how the kind of epistemological assumptions which we make or hold about knowledge profoundly affect how we go about uncovering knowledge of social behaviour. Here they refer to the decisions which the researcher will need to make about the kind of method(s) he or she will be using in their research as per their epistemological assumptions. That is, if knowledge, on one hand, is viewed as hard, objective and tangible, this demands of the researcher an observer role together with an allegiance to the methods of natural science such as testing, measuring, etc. If knowledge, on the other hand, is viewed as personal, subjective and unique, then this imposes on the researcher a rejection of the methods used by natural science and a greater involvement with their subjects. (p. 2)

\subsection{Research Design}

The research design deemed appropriate for this study is a descriptive quantitative content analysis. Content analysis, as described by Neuman (1997), is "a technique for gathering and analysing the content of text. The 'content' refers to words, meanings, pictures, symbols, ideas, themes, or any message that can be communicated. The 'text' is anything written, visual, or spoken that serves as a medium for communication" (pp. 272-273). Citing Kerlinger (2000), Wimmer and Dominick (2005) defines content analysis as a method of analysing communication in a systematic, objective and quantitative manner for the purpose of measuring variables.

Two main aims of using content analysis are to describe features of the message content and to make predictions about the effect of what is being analysed would have (Baran \& Davis, 2012; Rose, Spinks \& Canhoto, 2015). However, this study focuses on achieving the former aim, that is, "to describe features of the message content". This is the main reason for choosing a descriptive data analysis technique rather than analytical data analysis. Furthermore, the fact that the contents of newspapers can be studied systematically, objectively and quantitatively and inferences can be made thereby using content analysis makes the method suitable for this study (Olomojobi, 2017).

\subsection{Population, Sample Size and Sampling Technique}

The print media was chosen due to the permanent nature of the medium, availability and easy accessibility to contents, unlike the broadcast media (Olomojobi, 2017; Salman, 2016). The content of the issue of Daily Trust newspaper published on 7th July 2019 formed the accessible population of this study. The period was chosen because this study we wanted to understand the content of a typical national daily newspaper during a weekend (Sunday) with aim of comparing it with its content during week days (Mondays to Fridays), the technique of sampling was purposive. Daily Trust newspaper was selected based on the criteria that it is a national daily newspaper with widespread circulation across the country. This newspaper also has a strong online presence that complements the distribution of its print copies, further elevating its readership level among Nigerians. In addition, the newspaper was established by professionals who work in different media outfits before coming together to establish it, so, it was not formed by a single individual.

The complete enumeration or census technique, which involves selecting all units in the selected newspaper (McNamara, 2005) was applied to analyse the content of the selected newspaper. The complete enumeration or census technique is often seen as a form of purposive sampling, and as McNamara (2005, p. 13) affirms, it "provides the greatest possible representation when conducting content analysis". This technique was applied in order to have a comprehensive and accurate study of the selected newspaper, which was restricted to just a single issue (i.e., one day) due to the nature of this study, which is didactic. The 7th July 2019 issue of Daily Trust was the sample focus of the study, exempting all others. The selected issue was manually to exhaustively analyses it content quantitatively, based on frequency and percentage. 


\subsection{Research Instrument, Data Collection Procedure and Method of Data Analysis}

The research instrument used for the collection of data was the coding schedule. Coding schedule, according to Rose et al. (2015), requires "developing classification rules to assign coding units to particular categories or concepts" (p. 4). The coding schedule consist of the coding manual and the coding sheet. The coding manual is a structured instrument which provides the guide on how to complete the coding sheet. Given the nature of this study (which is didactic), no scientifically sophisticated coding procedure was applied. Coding schedule was used by the candidate to collect data from the selected national newspaper over a duration of 24 hours from 11 to 12 July 2019. Descriptive statistics was used to analyse data collected. The data was analysed manually, and 20 content categories and 14 units of analysis were identified. The sampling unit of this study was a weekend (Sunday) edition of Daily Trust newspaper published on 7th July 2019, as mentioned earlier.

\section{Results and Discussion}

\subsection{Results}

\subsubsection{Objective 1: Content Categories and Units of Analysis}

In the exhaustive quantitative content analysis of the selected newspaper, 20 mutually exclusive content categories and 14 units of analysis were identified as shown in Table 1. With this, Objective 1 was achieved. Arranged based on alphabetical order, the content categories range from Agriculture to Youth while the units of analysis range from Advertisement to Short stories. For convenience, the units of analysis are placed in the upper part of the table, with the content categories juxtaposed vertically, forming the left plank of the table. The various 'beat' subjects form the content categories while the elements that constitute the building agents of the newspaper content form the units of analysis. Except for a few units of analysis that are not 'traditionally' news related, e.g., advertisement and puzzle/quiz, most of them are.

Table 1. Content Categories and Units of Analysis of this Study

\begin{tabular}{|c|c|c|c|c|c|c|c|c|c|c|c|c|c|c|c|}
\hline & \multicolumn{15}{|c|}{ UNIT OF ANALYSIS } \\
\hline & S/No & 1 & 2 & 3 & 4 & 5 & 6 & 7 & 8 & 9 & 10 & 11 & 12 & 13 & 14 \\
\hline S/No & CONTENT CATEGORY & 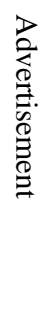 & 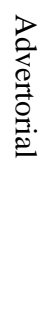 & 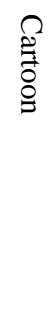 & 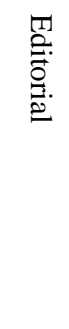 & 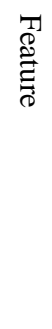 & 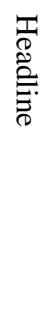 & 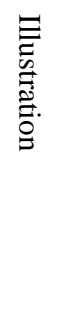 & 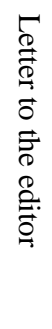 & $\begin{array}{l}Z \\
\substack{0 \\
\dot{n} \\
\infty}\end{array}$ & 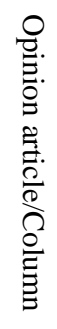 & 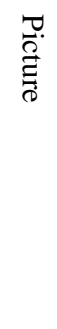 & $\begin{array}{l}\overrightarrow{0} \\
\mathbb{8} \\
\Xi\end{array}$ & 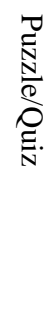 & 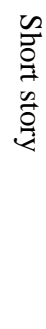 \\
\hline 1 & Agriculture & & & & & & & & & & & & & & \\
\hline 2 & Arts/Literature & & & & & & & & & & & & & & \\
\hline 3 & Business/Tourism & & & & & & & & & & & & & & \\
\hline 4 & Crime & & & & & & & & & & & & & & \\
\hline 5 & Crisis/Accident & & & & & & & & & & & & & & \\
\hline 6 & Education & & & & & & & & & & & & & & \\
\hline 7 & Fashion/Beauty & & & & & & & & & & & & & & \\
\hline 8 & Foreign/International & & & & & & & & & & & & & & \\
\hline 9 & Gender/Women & & & & & & & & & & & & & & \\
\hline 10 & Health and Nutrition & & & & & & & & & & & & & & \\
\hline 11 & Interview & & & & & & & & & & & & & & \\
\hline 12 & Investigation & & & & & & & & & & & & & & \\
\hline 13 & Judiciary & & & & & & & & & & & & & & \\
\hline 14 & Media & & & & & & & & & & & & & & \\
\hline 15 & Politics & & & & & & & & & & & & & & \\
\hline 16 & Religion/Philosophy & & & & & & & & & & & & & & \\
\hline 17 & Science and Technology & & & & & & & & & & & & & & \\
\hline 18 & Sports & & & & & & & & & & & & & & \\
\hline 19 & Weather/Climate & & & & & & & & & & & & & & \\
\hline 20 & Youth & & & & & & & & & & & & & & \\
\hline
\end{tabular}




\subsubsection{Objective 2: Analysis of Units of Analysis Variables based on Frequency and Percentage}

Tables $2 \mathrm{a}$ and $2 \mathrm{~b}$ (see Appendices A and B respectively) provide the detail information (data) about the entire content of the selected newspaper quantitatively by frequency and percentage. These two tables form the achievement of Objective 2 of this study. Each table contain quantitative information in frequency and percentage for each of the 14 units of analysis with each corresponding content category. The data for each unit of analysis and their total were computed discretely. Because the content categories are many and a single table (Table 2a) cannot accommodate all the data, another table (Table 2b) was added as a continuation of the content analysis data. Hence, each unit of analysis entry in Table $2 \mathrm{a}$ has a separate 'Total' row, containing only the summations of the frequencies and percentages of that given unit of analysis for the array of content categories in that table exclusively. While data in Table $2 b$ were computed in the same way as those in Table $2 a$, all the 'Overall Totals' in Table 2b, as the name implies, are the summations of the entire data for each of the unit of analysis entry in both of the tables. This means that each 'Overall Total' in Table $2 b=$ each 'Total' in Table 2a + each 'Total' in Table 2b. Concisely, each 'Overall Total' is the sum of the data entry for each unit of analysis across the entire array of content categories in both Tables $2 \mathrm{a}$ and $2 \mathrm{~b}$.

4.1.3 Objective 3: Dominant Variables

Table 3: Descriptive Analysis of the Distribution of Each Unit of Analysis Variable

\begin{tabular}{|c|c|c|c|}
\hline $\mathrm{S} / \mathrm{No}$ & Unit of Analysis Variable & Frequency & Percentage \\
\hline 1 & Headline & 129 & 30 \\
\hline 2 & Picture & 93 & 21.5 \\
\hline 3 & News & 72 & 16.62 \\
\hline 4 & Illustration & 47 & 10.8 \\
\hline 5 & Feature & 45 & 10.4 \\
\hline 6 & Short story & 18 & 4.15 \\
\hline 7 & Opinion article/Column & 11 & 2.54 \\
\hline 8 & Advertorial & 9 & 2.07 \\
\hline 9 & Letter to the editor & 4 & 0.9 \\
\hline 10 & Quiz/Puzzle & 3 & 0.7 \\
\hline 11 & Advertisement & 2 & 0.46 \\
\hline 12 & Poem & 2 & 0.46 \\
\hline 13 & Almanac/Calendar & 1 & 0.23 \\
\hline 14 & Editorial & 1 & 0.23 \\
\hline Total & & 433 & 100 \\
\hline
\end{tabular}

Table 3 shows the frequency-percentage quantified distribution of each of the 14 units of analysis in the entire content of the selected Daily Trust newspaper edition. The data in Table 3 and the data analysis and discussion that follow in the subsequent paragraphs indicate the achievement of Objective 3 of this study. A total of 433 (100\%) variables (units of analysis) were identified in the newspaper as shown in the Table. Units of analysis Almanac/Calendar and Editorial appeared the least, once each $(0.23 \%)$ respectively in the entire content of the newspaper. Traditionally, editorials appear only once in a typical tabloid newspaper issue. Closely following Almanac/Calendar and Editorial are Advertisements appeared twice $(0.46 \%)$, Poems appeared twice $(0.46 \%)$, Quiz/Puzzles appeared thrice $(0.7 \%)$ and Letters to the Editor appeared four times $(0.9 \%)$.

With 129 appearances, which is equivalent to nearly one-third (30\%) of the entire content of the newspaper, Headlines had the highest appearances and is the topmost dominant variable. Pictures appeared 93 times (21.5\%), which is distantly the second dominant variable. News stories is the third dominant variable, with 72 appearances (16.62\%). Illustrations and Feature stories came fourth and fifth with 47 (10.8\%) and 45 (10.4) appearances respectively. Short stories and Opinion/Columns followed distantly with 18 (4.15\%) and $11(2.54 \%)$ appearances respectively.

\subsection{Discussion}

\subsubsection{Objective 4: The Dominant Variables and Daily Trust Newspaper's Role in Agenda-Setting}

From the data in Tables 2a, $2 \mathrm{~b}$ (see Appendices A and B respectively) and 3, Headlines, Pictures and News stories were identified as the dominant variables in the entire content of the newspaper. Topping the list with a total of 129 appearances, headlines were identified as the most dominant variables. They were followed by Pictures, numbering 93 (21.5\%), which is slightly more than a quarter of the content. The third most dominant variable was News stories, which the newspaper featured 72 of them forming almost one-sixth of its entire content. As far as a tabloid newspaper such as Daily Trust is concerned, it is not surprising that headlines (of all types and categories) outnumber news stories, the major content of the newspaper, in fact, the element from which newspaper derives its name. Similarly, the number of 
pictures may not be surprising especially when we consider them as agents of hedonic motivation and monotony-breakers. Given that this study analysed a newspaper's content, not a magazine's content, pictures and illustrations (Illustrations, which appeared 47 times, $10.8 \%$ are the fourth dominant variables) should ordinarily, not outnumber the major editorial content of the newspaper such as news stories and features (Features are the fifth dominant variables in the content. They appeared 45 times, 10.4\%).

Moreover, a vast majority of the 47 illustrations are on Arts/Literature. This indicates that a salience has been attached to the issues of reading, writing and other acts of creativity such as painting. In addition to setting an agenda for the adoption and cultivation of self-development habits and behaviour such as reading, writing, painting, this also provides entertainment for the reader. However, since the newspaper under investigation is a weekend (Sunday) edition, we might reason with it that during weekends hard news are relatively less concentrated on as much as soft news and other relaxed content such as feature stories, arts/literature and 'photo news'; hence, picture would be likely to outnumber news.

Of the 93 pictures, only three are independent pictures (one on religion, Islam, one on politics and the third on international humanitarian service). Although pictures complement news stories, and sometimes, can act as news stories in themselves (e.g., independent pictures), pictures are liable to different shades of interpretations by readers, which, sometimes might be contrary to the newspaper's agenda-setting objectives and goals. Therefore, this study wants to argue that tabloid newspapers should always be tabloid newspapers regardless of time period in as much we are not talking about magazines. Unless newspapers (or weekend editions of newspaper) would want to turn into a kind of news magazines or 'newsmags', this study would argue that give newspapers what belong to newspapers and leave to magazines what belongs to magazines.

Applying the notions of the Agenda-Setting theory to this discourse, we will understand that this edition of Daily Trust newspaper capitalizes on giving salience to the prevalent insecurity and ethno-religious as well as the ravaging herdsmen-famers conflicts in various parts of the country. To be specific, of the 47 feature stories identified, $80 \%$ of them were on politics, the ongoing Fulani herdsmen and farmers conflict and President Buhari's controversial Rural Grazing Area (RUGA) project. In fact, about $90 \%$ of all the opinion articles/columns identified were written on the herdsmen-farmers conflict and its accompanying RUGA project 'cousin'.

Therefore, given that the major premise of the Agenda-Setting theory is that the media set the agenda for what the public would deem important based on the postulation that there is a correlation between the media's presentation of news and information and the level of significance the public accord to events and issues in the society; a phenomenon that often than not, renders public discourse revolve around issues that are frequently and consistently focused on by the media (Oyesomi et al., 2019); therefore, this edition of Daily Trust newspaper more likely than not, intended to set agenda of peace, tolerance, national consciousness and consolidation of Nigeria's unity in diversity for the Government, citizens and other media outlets.

Furthermore, given that the 2019 elections have been barely four months off, and the newly elected governments (both at the federal and state levels) are yet to appoint their cabinets and are warming up toward celebrating their One Hundred Days in Office (OHDiO) having been barely two months since their inauguration on $29^{\text {th }}$ May 2019, about $50 \%$ of all news stories and $40 \%$ of all opinion articles/columns were on politics and governance, e.g., issues on National Assembly leadership, Senator Elisha Ishaku Abbo's crisis of assaulting a sales lady at a shopping mall in Abuja. Importantly, even the editorial titled "From RUGA to NLTP", was on the immense advantages of the RUGA project and its 'cousin', the National Livestock Transformation Project (NLTP), which was proposed by the Buhari Administration and adopted by the National economic Council for possible implementation. NLTP is a 10-year programme aimed at economic investment. Conflict resolution, law and order, humanitarian relief, information, education and strategic communication. The programme is estimated to cost N179 billion. With news stories and other key editorial content revolving around such lofty journalism practices such as peace and development journalism, there is no doubt to what agenda this edition of Daily Trust newspaper intends to set to the public, the Government and the media.

Furthermore, Table 3 shows that information about Almanac/Calendar appeared in two content categories only, namely Religion/Philosophy and Weather/Climate, both in Table 2b, specifically, the entry appeared under Religion/Philosophy is information about Muslims prayer times while the other one was about local weather forecast. Even though by frequency/percentage analysis religion-specific content such as Muslim prayer time calendar, the magnitude of the content says a lot about the newspaper's agenda-setting role toward providing religious education content for the benefits of the adherents of one of the major religions in Nigeria (Pate, 2009), who invariably form the majority among the population in the geopolitical zone where the newspaper has one of the highest acceptance and readership rates.

Extremely little attention was dedicated to weather/climate and general calendar issues in that issue of the newspaper. When this is related to the agenda-setting theoretical framework, we will understand that neither the newspaper 
intended to set any agenda to the audience regarding weather/climate (despite most if not all parts of Nigeria that the newspaper's circulation reaches are in rainy season) nor the audience seemed to have set any agenda for the newspaper. Regarding the current season, ordinarily, one would expect to read more about, and interact with more weather-related content. From political economy perspective, we may hypothesize that probably weather/climate related content do not attract expected revenues or were not handy.

Advertisement appeared twice only, under content categories Business/Tourism in Table 2a and Politics in Table 2b, indicating that adverts were less focused on despite being a weekend edition. Probably, more adverts were not handy. Given the pivotal position advertisements hold in the life of a typical Nigeria tabloid such as Daily Trust newspaper, we may say that adverts had not been handy, otherwise we would have seen lots of them in this weekend edition of the newspaper.

Of the 20 categories of analysis (subjects), Arts/Literature, Business/Tourism, Crime, Crisis/Accident, Education, Media, Politics, investigation, Religion/Philosophy, and Beauty/Fashion were among the most dominants. However, politics and media are the most dominant. From whoever angle we look at the entire content of the newspaper, one subject is overarchingly dominant. It is politics. A vast majority of the editorial content: news, pictures, headlines, feature stories, opinion articles/columns, and even the editorial revolve around political themes and issues (e.g., governance, parliament, conflict, party politics, socio-political issues and conflicts). An agenda for national unity, peaceful coo-existence and socio-economic development has been craftly set by the newspaper. What remains now is for whom the agenda was set to regard it and act accordingly or provide alternative, positively agendas.

\section{Conclusion}

A quantitative content analysis of a weekend (Sunday) edition of Daily Trust newspaper published on $7^{\text {th }}$ July 2019 was performed and the findings show that the newspaper contains a total of 433 editorial content (units of analysis), ranging from news stories to short stories. As many as 20 subjects (content categories) and 14 editorial elements (units of analysis, or variables) were identified. The first, second and third most dominant editorial content are headlines, pictures and news stories respectively. Next in dominance significance are illustrations and feature stories. Several opinion articles/columns and advertorials were also identified with most of the former revolving around developments and conflicts in politics (governance, parliament, party politics) and socio-cultural politics and conflicts (e.g., the RUGA project, the Fulani herdsmen and farmers conflict, etc.). In fact, a great deal of the news and news-related information content attempt setting an agenda for peace, tolerance and co-existence, prioritising national interest over personal, political or political interests, prioritising economic diversification through agriculture and tourism and prioritising positive national developments over sentiments, ethnicity and regionalism. This edition of the newspaper demonstrated a potent agenda-setting effort toward instilling in the reader the urge to adopt self-development as means of earning livelihood and avoiding boredom and idleness, especially for the youth. Investigative journalism and interview have also been given substantial attention in this edition of the newspaper. The newspaper should emphasise on investigative journalism and maintain the peace and development journalism to strengthen its profile (Pate, 2009) and for nationalism agenda.

\section{References}

Akubor, E. (2016). Campaigns and electioneering: Reflecting on the 2015 general elections in Nigeria. Osun, Nigeria: OAU.

Alawode, S. O., \& Adesanya, O. O. (2016). Content analysis of 2015 election political advertisements in selected national dailies of Nigeria. European Scientific Journal, 12(5), 1857-7881. https://doi.org/10.19044/esj.2016.v12n5p234

Al-Saadi, H. (2014). Demystifying ontology and epistemology in research methods. (Unpublished doctoral research thesis), University of Sheffield, UK. Retrieved July 17, 2019 from: https://www.researchgate.net/publication/260244813

Baran, S. J., \& Davis, D. K. (2012). Mass communication theory: Foundations, ferment, and future (6 ${ }^{\text {th }}$ ed.). Boston: Wadsworth Cengage.

Berelson, B. (1952). Content analysis in communication research. New York: Free Press.

Bim-Bad, B. M., \& Egorova, L. I. (2016). Interaction between philosophy of education and teaching practice. International Journal of Environmental and Science Education, 11(10), 3385-3393.

Blaikie, N. (2010). Designing social research. New York: Polity Press.

Bryman, A. (2012). Social research methods (4 ${ }^{\text {th }}$ ed.). London: Oxford University Press.

Carley, K. (1993). Coding choices for textual analysis: A comparison of content analysis and mapping analysis. 
Sociological Methodology, 23, 75-126. https://doi.org/10.2307/271007

Cohen, B. (1963). The press and foreign policy. Princeton: Princeton University Press.

Daramola, I. (2005). Mass media and society. Lagos: Rothan Press Limited.

Daramola, I. (2013). History and development of mass media in Nigeria ( $2^{\text {nd }}$ ed.). Lagos: Rothan Press Ltd.

DeFleur, M. L. (2010). Mass communication theories: Explaining origins, processes and effects. Boston: Allyn \& Bacon.

Duyile, D. (1987). Makers of Nigerian Press. Lagos: Gong Communications Nigeria Ltd.

Grossberg, L., Wartella, E., Whitney, C., \& Wise, M. (2006). Media making: Media in a popular culture. California: Sage Publications.

Janowitz, M. (1969). Sociological models and social policy. ARSP: Archiv furRechts-und-Sozialphilosophie/Archives for Social Philosophy of Law of Social Philosophy, 55(3), 305-321.

Kaplan, A. (1943). Content analysis and the theory of signs. Philosophy of Science, 10(4), 230-27. https://doi.org/10.1086/286814

Kassarjian, H. H. (1977). Content analysis in consumer research. Journal of Consumer Research, 4(1), 8-18. https://doi.org/10.1086/208674

Kiousis, S., \& McCombs, M. (2004). Agenda-setting effects and attitude strength: Political figures during the 1996 presidential election. Communication Research, 31(1), 36-57. https://doi.org/10.1177/0093650203260205

Kolbe, R. H., \& Burnett, M. S. (1991). Content-analysis research: An examination of applications with directive for improving research reliability and objectivity. Journal of Consumer Research, 18(2), 243-250. https://doi.org/10.1086/209256

Krippendorff, K. (2004). Content analysis: An introduction to its methodology. Thousand Oaks: Sage Publications.

McNamara, J. R. (2005). Media content analysis: Its uses, benefits and best practice methodology. Asia Pacific Public Relations Journal, 6(1), 1-34.

Maikaba, B. (2017). The use of new media in journalism education (Abstract, Ch 5). In the Association of Communication Scholars and Professionals of Nigeria (ACSPN) Book Series 2. Ontario: Canada University Press. Retrieved from https://www.acspn.com.ng/Chapter-5-The-Use-of-New-Media-in-Journalism-Education

McCombs, M. E. (2005). A look at agenda-setting: Past, present and future. Journalism Studies, 6(4), 543-557. https://doi.org/10.1080/14616700500250438

Mitchell, R. E. (1967). The use of content analysis for explanatory studies. Public Opinion Quarterly, 31(2), 230-241. https://doi.org/10.1086/267515

Neuendorf, K. (2002). The content analysis guidebook. Thousand Oaks, CA: Sage Publications.

Neuman, R. W. L., Jan. G. S. M., \& Bae, S. Y. (2014). The dynamics of public attention: Agenda-setting theory meets big data. Journal of Communication, 64(2) 193-214. https://doi.org/10.1111/jcom.12088

Neuman, W. (1997). Social research methods: Qualitative and quantitative approaches. Needham Heights, MA: Allyn \& Bacon.

Olomojobi, O. T. (2017). National newspapers' coverage of the conflict between herders and farmers in Nigeria. (Unpublished MSc dissertation), Babcock University, Ilishan-Remo, Ogun State, Nigeria.

Oyesomi, K., Salawu, A., \& Oyenankeya, K. (2019). Newspapers' compliance with the code of election coverage of the 2015 elections and citizens participation: Implication for journalism education and professionalism. African Renaissance, 16(1), 41-64. https://doi.org/10.31920/2516-5305/2019/V16n1a3

Pate, U. A. (2009). Media and religion: A study of three cases in northern Nigeria. Professor Umar Pate (University of Maiduguri) blog, June 17. Retrieved from http://umarpate.blogspot.com/2009/06/media-and-religion-study-three-cases.html

Pate, U. A. (2009). Strengthening media capacity for investigative journalism through institutions-based curriculum. Professor Umar Pate (University of Maiduguri) blog, June 17. Retrieved from http://umarpate.blogspot.com/2009/strengthening-media-capacity-for.html

Rose, S., Spinks N., \& Canhoto, A. I. (2015). Management research: Applying the principles. London: Routledge. https://doi.org/10.4324/9781315819198 
Salman. A. (2016). Social media and Agenda-Setting: Implications on political agenda. Malaysian Journal of Communication, 32(1), 607-623. https://doi.org/10.17576/JKMJC-2016-3201-19

Stepashko L. A. (1999). Filosofiya i istoriya obrazovaniya [Philosophy and history of education]. Moskow.: Publishing house Flinta.

Wimmer, D. R., \& Dominick, J. R. (2005). Mass media research: An introduction. Canada: Wadsworth Cengage Learning.

Winham, G. R. (1969). Quantitative methods in foreign policy analysis. Canadian Journal of Political Science/Revue Canadienne de Science Politique, 2(2), 187-199. https://doi.org/10.1017/S0008423900024884

Yusha'u, M. J. (2009). Coverage of corruption scandals in the Nigerian press: A comparative analysis of northern and southern newspapers. (Unpublished doctoral thesis), University of Sheffield, the United Kingdom (UK).

Zhu, J., \& Blood, D. (1997). Media agenda-setting theory: Telling the public what to think about. In B. Kovacic (Ed.), Emerging theory of human communications (pp. 88-114). New York: State University of New York Press.

\section{Appendix A}

Table 2a. Percentage and Frequency of Units of Analysis by Categories

\begin{tabular}{|c|c|c|c|c|c|c|c|c|c|c|c|c|c|c|c|c|c|c|c|c|c|c|c|c|}
\hline \multirow[t]{3}{*}{ UNIT OF ANALYSIS } & \multicolumn{24}{|c|}{ CONTENT CATEGORY } \\
\hline & \multicolumn{2}{|c|}{ Agriculture } & \multicolumn{2}{|c|}{$\begin{array}{l}\text { Arts/ } \\
\text { Lit.* }\end{array}$} & \multicolumn{2}{|c|}{$\begin{array}{c}\text { Business/ } \\
\text { Tourism }\end{array}$} & \multicolumn{2}{|c|}{ Crime } & \multicolumn{2}{|c|}{$\begin{array}{c}\text { Crisis/ } \\
\text { Accident }\end{array}$} & \multicolumn{2}{|c|}{ Education } & \multicolumn{2}{|c|}{$\begin{array}{c}\text { Fashion/ } \\
\text { Beauty }\end{array}$} & \multicolumn{2}{|c|}{$\begin{array}{c}\text { Foreign/ } \\
\text { International }\end{array}$} & \multicolumn{2}{|c|}{$\begin{array}{l}\text { Gender/ } \\
\text { Women }\end{array}$} & \multicolumn{2}{|c|}{$\begin{array}{l}\text { Health\& } \\
\text { Nutrition }\end{array}$} & \multicolumn{2}{|c|}{ Interview } & \multicolumn{2}{|c|}{ Investigation } \\
\hline & $f$ & $\%$ & $f$ & $\%$ & $f$ & $\%$ & $f$ & $\%$ & $f$ & $\%$ & $f$ & $\%$ & $f$ & $\%$ & $f$ & $\%$ & $f$ & $\%$ & $f$ & $\%$ & $f$ & $\%$ & $f$ & $\%$ \\
\hline Almanac/ & 0 & 0 & 0 & 0 & 0 & 0 & 0 & 0 & 0 & 0 & 0 & 0 & 0 & 0 & 0 & 0 & 0 & 0 & 0 & 0 & 0 & 0 & 0 & 0 \\
\hline \multicolumn{25}{|l|}{ Calendar } \\
\hline Total & & & & & & & & & & & & & & & & & & & & & & & 0.0 & $0.0 \%$ \\
\hline Advertisement & 0 & 0 & 0 & 0 & 1 & 50 & 0 & 0 & 0 & 0 & 0 & 0 & 0 & 0 & 0 & 0 & 0 & 0 & 0 & 0 & 0 & 0 & 0 & 0 \\
\hline Total & & & & & & & & & & & & & & & & & & & & & & & 1 & $50 \%$ \\
\hline Advertorial & 0 & 0 & 0 & 0 & 1 & 11.1 & 0 & 0 & 0 & 0 & 1 & 11.1 & 0 & 0 & 0 & 0 & 0 & 0 & 0 & 0 & 0 & 0 & 0 & 0 \\
\hline Total & & & & & & & & & & & & & & & & & & & & & & & 2 & $22.2 \%$ \\
\hline Cartoon & 0 & 0 & 0 & 0 & 0 & 0 & 0 & 0 & 0 & 0 & 0 & 0 & 0 & 0 & 0 & 0 & 0 & 0 & 0 & 0 & 0 & 0 & 0 & 0 \\
\hline Total & & & & & & & & & & & & & & & & & & & & & & & 0.0 & $0.0 \%$ \\
\hline Editorial & 0 & 0 & 0 & 0 & 0 & 0 & 0 & 0 & 0 & 0 & 0 & 0 & 0 & 0 & 0 & 0 & 0 & 0 & 0 & 0 & 0 & 0 & 0 & 0 \\
\hline Total & & & & & & & & & & & & & & & & & & & & & & & 0.0 & $0.0 \%$ \\
\hline Feature & 2 & 4.4 & 5 & 11.1 & 2 & 4.4 & 1 & 2.2 & 2 & 4.4 & 3 & 6.7 & 0 & 0 & 0 & 0 & 1 & 2.2 & 1 & 2.2 & 7 & 15.6 & 5 & 11.1 \\
\hline Total & & & & & & & & & & & & & & & & & & & & & & & 29 & $64.4 \%$ \\
\hline Headline & 9 & 6.10 & 10 & 7.8 & 10 & 7.8 & 9 & 6.10 & 5 & 3.9 & 12 & 9.3 & 0 & 0 & 2 & 1.55 & 7 & 5.4 & 6 & 4.7 & 10 & 7.8 & 8 & 6.2 \\
\hline Total & & & & & & & & & & & & & & & & & & & & & & & 61 & $47.3 \%$ \\
\hline Illustration & 0 & 0 & 20 & 42.6 & 0 & 0 & 1 & 2.1 & 0 & 0 & 0 & 0 & 2 & 4.25 & 0 & 0 & 2 & 4.25 & 1 & 2.1 & 0 & 0 & 3 & 6.38 \\
\hline Total & & & & & & & & & & & & & & & & & & & & & & & 29 & $61.7 \%$ \\
\hline Letter to the Editor & 0 & 0 & 0 & 0 & 1 & 25 & 0 & 0 & 0 & 0 & 0 & 0 & 0 & 0 & 0 & 0 & 0 & 0 & 0 & 0 & 0 & 0 & 0 & 0 \\
\hline Total & & & & & & & & & & & & & & & & & & & & & & & 1 & $25 \%$ \\
\hline News & 3 & 4.16 & 3 & 4.16 & 5 & 6.9 & 6 & 8.3 & 2 & 2.8 & 7 & 9.7 & 0 & 0 & 2 & 2.8 & 2 & 2.8 & 5 & 6.9 & 3 & 4.16 & 3 & 4.16 \\
\hline Total & & & & & & & & & & & & & & & & & & & & & & & 41 & $56.9 \%$ \\
\hline Opinion article/ & 0 & 0 & 0 & 0 & 0 & 0 & 0 & 0 & 1 & 9.1 & 0 & 0 & 0 & 0 & 0 & 0 & 0 & 0 & 0 & 0 & 0 & 0 & 0 & 0 \\
\hline \multicolumn{25}{|l|}{ Column } \\
\hline Total & & & & & & & & & & & & & & & & & & & & & & & 1 & $9.1 \%$ \\
\hline Picture & 6 & 6.5 & 9 & 9.7 & 5 & 5.4 & 5 & 5.4 & 3 & 3.2 & 4 & 4.3 & 4 & 4.3 & 3 & 3.2 & 12 & 12.9 & 7 & 7.5 & 17 & 18.5 & 6 & 6.5 \\
\hline Total & & & & & & & & & & & & & & & & & & & & & & & 75 & $80.6 \%$ \\
\hline Poem & 0 & 0 & 2 & & 0 & 0 & 0 & 0 & 0 & 0 & 0 & 0 & 0 & 0 & 0 & 0 & 0 & 0 & 0 & 0 & 0 & 0 & 0 & 0 \\
\hline Total & & & & & & & & & & & & & & & & & & & & & & & 2 & $100 \%$ \\
\hline Puzzle/Quiz & 0 & 0 & 2 & 66.7 & 0 & 0 & 0 & 0 & 0 & 0 & 1 & 33.3 & 0 & 0 & 0 & 0 & 0 & 0 & 0 & 0 & 0 & 0 & 0 & 0 \\
\hline Total & & & & & & & & & & & & & & & & & & & & & & & 3 & $100 \%$ \\
\hline Short story & 0 & 0 & 1 & 5.6 & 2 & 11.1 & 2 & 11.1 & 0 & 0 & 0 & 0 & 0 & 0 & 0 & 0 & 4 & 22.2 & 0 & 0 & 0 & 0 & 0 & 0 \\
\hline Total & & & & & & & & & & & & & & & & & & & & & & & 9 & $50 \%$ \\
\hline
\end{tabular}

Note: $f=$ frequency $; *$ Literature; $0=$ Nil 


\section{Appendix A}

Table 2b. Continuation of the Percentage and Frequency of Units of Analysis by Categories

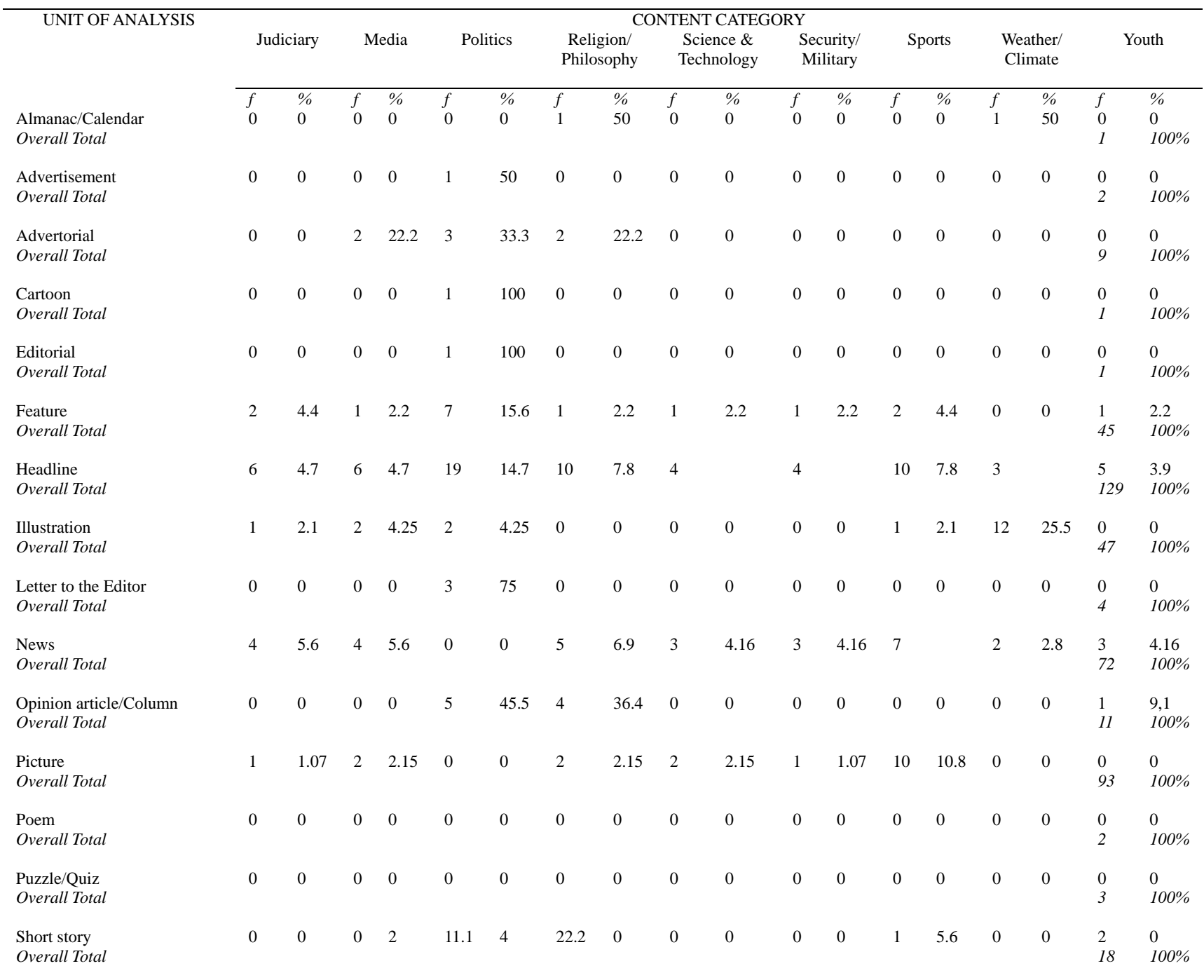

Note: $f=$ frequency; $0=N i l$

\section{Copyrights}

Copyright for this article is retained by the author(s), with first publication rights granted to the journal.

This is an open-access article distributed under the terms and conditions of the Creative Commons Attribution license which permits unrestricted use, distribution, and reproduction in any medium, provided the original work is properly cited. 